\title{
Evaluation of Nurses' Attitudes Toward Medical Errors
}

\section{Hemşirelerin Tıbbi Hatalara İlişkin Tutumlarının Değerlendirilmesi}

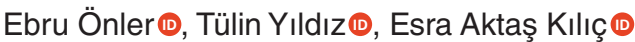

SHYD 2021;8(1):86-93

doi:10.5222/SHYD.2021.99815

Cite as: Önler E, Yıldız T, Aktaş Kılıç E. Evaluation of nurses' attitudes toward medical errors. Sağlık ve Hemşirelik Yönetim Dergisi. $2021 ; 8(1): 86-93$.

\begin{abstract}
Aim: This study was realized with the aim to evaluate nurses' attitudes toward medical errors. Method: Data were collected from 149 nurses in a university hospital in Turkey, using the Scale of Attitudes toward Medical Errors developed by Güleç and Seren Intepeler (2013) and a staff information form prepared in line with the literature data .

Results: Nurses' attitudes toward errors were generally positive, and intensive care unit (ICU) nurses were found to have more positive attitudes toward errors than ward nurses. The factors that caused medical errors included an increasing number of patients per shift, a workforce shortage, an intensifying workload, and lack of knowledge and experience. While the majority of the nurses believed that reporting errors decreased the number of errors, most of them refrained from reporting errors for which they were responsible.

Conclusion: The results may be useful for nurse managers and leaders to reach a more comprehensive understanding of nurses' attitudes toward medical errors and to encourage them to support their staff and improving their working environment.
\end{abstract}

Keywords: Patient safety, medical errors, nurses, second victim syndrome, just culture

\section{Öz}

Amaç: Bu araştırma, hemşirelerin tıbbi hatalara ilişkin tutumlarını değerlendirmek amacıyla gerçekleştirildi.

Yöntem: Araştırmanın verileri, bir üniversite hastanesinde görevli 149 hemşireden, Güleç ve Seren İntepeler (2013) tarafından geliştirilen Tıbbi Hatalarda Tutum Ölçeği ve literatür doğrultusunda hazırlanan çalışan bilgi formu kullanılarak toplandı.

Bulgular: Hemşirelerin genellikle tıbbi hatalara ilişkin olumlu tutumlarının olduğu, yoğun bakım hemşirelerin hatalara ilişkin servis hemşirelerinden daha olumlu tutumları olduğu bulundu. Hatalara neden olan faktörler, hasta sayısının fazla olması, çalışan sayısının az olması, iş yükününün fazla olması, bilgi ve deneyim eksikliği olarak belirlendi. Hemşirelerin çoğunluğu, hataların rapor edilmesinin hata sayısını azalttığına inanırken, çoğu sorumlu oldukları hataları bildirmekten kaçınmaktadır.

Sonuç: Bu araştırmanın sonuçları, hemşire yöneticileri ve liderlerinin hemşirelerin tıbbi hatalara ilişkin tutumlarını daha kapsamlı bir şekilde anlamaları, onları desteklemeleri ve çalışma ortamlarını geliştirmeleri açısından yararlı olabilir.

Anahtar sözcükler: Hasta güvenliği, tıbbi hatalar, hemşireler, ikinci kurban sendromu, adil kültür
Recieved / Geliş:

26.05.2020

Accepted / Kabul:

19.03.2021

Published Online / Online Yayın:

28.04.2021

Corresponding author /

Sorumlu yazar:

Ebru Onler

Tekirdağ Namık Kemal University, Department of Nursing,

Tekirdağ/ Turkey

eonler@nku.edu.tr

ORCID: 0000-0003-2117-1952

T. Yıldız 0000-0002-4981-6671

E. Aktaş Kılıç 0000-0002-1196-7802

Tekirdağ Namık Kemal University,

Department of Nursing, Tekirdağ/ Turkey 


\section{Background}

Medical errors, including medication errors, incorrect procedures, hospital-acquired conditions, missed delirium, missed care, etc., are part of complex dynamic processes that are often situated in a high-stress working environment (Koehn, Ebright and Draucker, 2016). The prevalence of medical errors in healthcare has been found to be higher in recent years (Heyland, Ilan, Jiang, You and Dodek, 2016; Matin et al., 2018; Tawfik et al., 2018). Finding ways to lessen the number of medical errors is important because they are responsible for a significant number of injuries and deaths in hospitalized patients annually (Makary and Daniel, 2016).

While medical errors harm patients and their families, they can also exert harmful effects, such as psychological distress, on healthcare staff (Koehn et al., 2016; Winning et al., 2018). In a study by Zhang, Li, Guo and Lee (2019), half of the nurses studied experienced psychological distress, and more than one quarter reported turnover intentions due to medical errors.

Despite all of their harmful effects, medical errors are mostly preventable (James, 2013). Establishing a patient safety culture (PSC) helps to avoid medical errors and reduces the harm they pose to patients (Sammer, Lykens, Singh, Mains and Lackan, 2010). The attitudes of healthcare staff toward medical errors are an essential component of PSC (Tunçer Ünver and Harmancı Seren, 2013). Attitudes toward medical errors include perceptions and understandings of, as well as approaches to medical errors (Güleç and Seren-Intepeler, 2013).

In scholarly literature on attitudes towards medical errors, the main focus is on reporting, analyzing, and learning from medical errors to minimize risks to patient safety. Nevertheless, under-reporting of medical errors remains a global issue (Chiang, Lee, Lin and Ma, 2019; Matin et al., 2018). Therefore, there are several worldwide efforts to increase patient safety incident reporting rates (Archer et al., 2017; Chiang et al., 2019; Howell et al., 2017).

Nurses play a vital role in avoiding medical errors that can cause serious and fatal adverse events by providing ongoing assessment, monitoring and detecting of changes in health status (Dykes, Rothschild and Hurley, 2010). Nurses are also at the greatest risk of being blamed for a medical error among healthcare staff, as they provide the most direct care for patients (Harrison et al., 2015).

Thus, it is important to determine nurses' attitudes toward medical errors to avoid errors and support nurses who are secondary victims of errors. Data collected in Turkey, a developing country with emerging healthcare systems, will contribute to the international body of knowledge on medical errors. To contribute to the scholarly literature on this topic, this descriptive questionnaire study aimed to evaluate nurses' attitudes toward medical errors.

\section{Method}

Aim: This study aimed to evaluate nurses' attitudes toward medical errors.

Research Questions: The following research questions were asked:

- Are nurses' attitudes toward medical errors significantly associated with their age, job experience and working unit?

- Are nurses' perceptions of medical errors significantly associated with their age, job experience and working unit?

- Are nurses' approaches to medical errors significantly associated with their age, job experience and working unit?

- Are nurses' opinions about the causes of medical errors significantly associated with their age, job experience and working unit?

Sample: The study was conducted in a university hospital in the western part of Turkey. A total of 242 registered nurses (RNs) were working in the university hospital. A convenient sample of nurses working in the hospital was used. The sample population included 149 nurses with a $95 \%$ confidence interval and a $\pm 5 \%$ sampling error. The overall response rate was $62 \%$.

Instruments: The Scale of Attitudes toward Medical Errors is a 5-point Likert-type scale developed by Güleç and SerenIntepeler (2013) to determine nurses' and physicians' attitudes toward medical errors. The self-reported scale consisted of 16 items and 3 subscales. The subscales were perceptions of medical errors, approaches to medical errors, and causes of medical errors. Items 10 and 13 were scored in reverse. The scale score was obtained by dividing the total scale score by the number of scale items. The subscale scores were obtained by dividing the total subscale scores by the number of subscale items. They were then evaluated between 1-5 points. The cut-off point for the scale was 3 , meaning that the medical error attitudes of staff members who scored below 3 were considered negative, while the medical error attitudes of staff members who scored above 3 were considered positive. A negative attitude indicates that the staff member is less aware of medical errors and error reporting. A positive attitude indicates that the staff member is aware of the importance of medical mistakes and error reporting. In Güleç and Seren-Intepeler's study, Cronbach's alpha coefficient was 0.75 (Güleç and Seren-İntepeler, 2013). In this study, Cronbach's alpha coefficient was 0.70 . Additionally, the staff information form consisted of information regarding the staff member's age, job experience and working unit. 


\section{Data collection}

Data was collected from February 2017 through May 2017. The researchers distributed the data collection tools to all nurses who were willing to participate in the study, and they collected the responses 2-7 days later.

Data analysis: Data analysis was performed using Statistical Package for the Social Sciences (SPSS 18, IBM Corp, Armonk, New York). Mean, standard deviation, frequency, percentage and the Kruskal- Wallis and Mann-Whitney $U$ tests were used to analyse data. Results were evaluated with a $p<0.05$ significance level.

Ethical considerations: The local Ethics Committee approved this study, under registration number 2017/43/04/03, with the application date of April 27, 2017. Written permission from the hospital and informed consent from each of the participants was obtained for the research., The researchers obtained permission from the developer to use the scale in the survey..

Limitations: This study is not without limitations. Data were collected from one university hospital. Therefore, the results of this study are limited to the responses given by the nurses in the sample group and cannot be generalized to all Turkish hospitals.

\section{Results}

The majority of the nurses surveyed were in the age range of $20-24$ years $(50.3 \%)$. The greatest percentage of nurses had a job experience of $1-5$ years (51\%). The nurses were working the inpatient ward $(43 \%)$, in the operating room (OR) (18.8\%), in the emergency room (18.1\%), and intensive care unit (ICU) ( $20.1 \%)$ (Table 1).

Nurses' score on the Scale of Attitudes toward Medical Errors was $3.920 \pm 0.346$. Scores for the subscales - perceptions of medical errors, approaches to medical errors and causes of medical errors - were 2.849 $\pm 0.631,4.076 \pm 0.454$ and 4.070 \pm 0.411 , respectively. Only the perceptions of medical errors subscale score was lower than the cut-off point of 3 .

Table 1. Characteristics of the study population $(\mathrm{N}=149)$

\begin{tabular}{lll} 
Variable & Frequency $(\mathbf{n})$ & Percentage (\%) \\
\hline Age (years) & & \\
\hline $20-24$ & 75 & 50.34 \\
$25-29$ & 47 & 31.54 \\
$30-59$ & 27 & 18.12 \\
\hline Job experience (years) & & \\
\hline$<1$ & 30 & 20.13 \\
$1-5$ & 76 & 51.01 \\
$6-10$ & 43 & 28.86 \\
\hline
\end{tabular}

\section{Working unit}

\begin{tabular}{llr}
\hline Inpatient ward & 64 & 42.95 \\
Emergency & 27 & 18.12 \\
Operating room & 28 & 18.80 \\
Intensive care unit & 30 & 20.13
\end{tabular}

In relation to age, there was no statistical difference between the total scale scores $(K W=4.265 ; P=0.119)$ and the subscale scores as follows: perceptions of medical errors $(K W=2.236 ; \mathrm{P}=0.327)$, approaches to medical errors $(K W=$ 5.263; $P=0.072)$ and causes of medical errors $(K W=1.300 ; P=0.522)$ (Table 2$)$. In relation to job experience, there was no statistical difference between the total scale scores $(K W=0.111 ; P=0.946)$ and the subscale scores as follows: perceptions of medical errors $(K W=0.117 ; \mathrm{P}=0.943)$, approaches to medical errors $(K W=0.082 ; \mathrm{P}=0.960)$ and causes of medical errors $(K W=1.177 ; P=0.555)$ (Table 2). In relation to working unit, although there was no statistical difference between the subscale scores - perceptions of medical errors $(K W=4.033 ; P=0.258)$, approaches to medical errors $(K W=4.492 ; P=$ $0.213)$ and causes of medical errors $(K W=6.260 ; P=0.100)$ - a statistically significant difference was detected between the subscale scores and the total scale score $(K W=8.297 ; \mathrm{P}=0.040<0.05)$ (Table 2). The Mann- Whitney $U$ test was used to determine from which group the difference originated. According to the test, ICU nurses' scores for the total scale (4.040 $\pm 0.312)$ were higher than the total scale scores for nurses working in inpatient wards $(3.832 \pm 0.326)$. 
Table 2. Nurses' attitudes towards medical errors by age, job experience and working unit $(N=149)$

\begin{tabular}{|c|c|c|c|c|}
\hline Variable & Mean & SD & KW & $\mathbf{P}$ \\
\hline \multicolumn{5}{|c|}{ Age groups (years) } \\
\hline \multicolumn{5}{|c|}{ The perception of medical errors } \\
\hline $20-24$ & 2.873 & 0.514 & \multirow{3}{*}{2.236} & \multirow{3}{*}{0.327} \\
\hline $25-29$ & 2.894 & 0.751 & & \\
\hline $30-59$ & 2.704 & 0.697 & & \\
\hline \multicolumn{5}{|c|}{ Approach to medical errors } \\
\hline $20-24$ & 4.149 & 0.448 & \multirow{3}{*}{5.263} & \multirow{3}{*}{0.072} \\
\hline $25-29$ & 4.027 & 0.433 & & \\
\hline $30-59$ & 3.958 & 0.487 & & \\
\hline \multicolumn{5}{|c|}{ Causes of medical errors } \\
\hline $20-24$ & 4.109 & 0.400 & \multirow{3}{*}{1.300} & \multirow{3}{*}{0.522} \\
\hline $25-29$ & 4.012 & 0.408 & & \\
\hline $30-59$ & 4.064 & 0.451 & & \\
\hline \multicolumn{5}{|l|}{ Total scale scores } \\
\hline $20-24$ & 3.972 & 0.337 & \multirow{3}{*}{4.265} & \multirow{3}{*}{0.119} \\
\hline $25-29$ & 3.879 & 0.326 & & \\
\hline $30-59$ & 3.847 & 0.391 & & \\
\hline \multicolumn{5}{|c|}{ Job experience (years) } \\
\hline \multicolumn{5}{|c|}{ The perception of medical errors (years) } \\
\hline$<1$ & 2.850 & 0.544 & \multirow{3}{*}{0.117} & \multirow{3}{*}{0.943} \\
\hline $1-5$ & 2.862 & 0.598 & & \\
\hline $6-10$ & 2.826 & 0.747 & & \\
\hline \multicolumn{5}{|c|}{ Approach to medical errors (years) } \\
\hline$<1$ & 4.091 & 0.432 & \multirow{3}{*}{0.082} & \\
\hline $1-5$ & 4.073 & 0.478 & & 0.960 \\
\hline $6-10$ & 4.070 & 0.437 & & \\
\hline Causes of medic & & & & \\
\hline$<1$ year & 4.000 & 0.463 & & \\
\hline $1-5$ & 4.083 & 0.351 & 1.177 & 0.555 \\
\hline $6-10$ & 4.096 & 0.474 & & \\
\hline Total scale score & & & & \\
\hline$<1$ & 3.896 & 0.356 & & 0.946 \\
\hline $1-5$ & 3.926 & 0.317 & 0.111 & \\
\hline $6-10$ & 3.926 & 0.392 & & \\
\hline Working unit & & & & \\
\hline The perception & & & & \\
\hline Inpatient ward & 2.719 & 0.642 & & \\
\hline Emergency & 2.852 & 0.617 & 4033 & 258 \\
\hline OR & 2.911 & 0.452 & 4.033 & 0.258 \\
\hline ICU & 3.067 & 0.716 & & \\
\hline Approach to me & & & & \\
\hline Inpatient ward & 3.987 & 0.432 & & \\
\hline Emergency & 4.127 & 0.362 & 4492 & 0213 \\
\hline OR & 4.158 & 0.513 & 4.492 & 0.213 \\
\hline $\mathrm{ICU}$ & 4.143 & 0.505 & & \\
\hline Causes of medic & & & & \\
\hline Inpatient ward & 3.996 & 0.404 & & \\
\hline Emergency & 4.021 & 0.450 & 6260 & 0.100 \\
\hline OR & 4.133 & 0.424 & $0 . \angle 00$ & \\
\hline $\mathrm{ICU}$ & 4.214 & 0.347 & & \\
\hline Total scale & & & & \\
\hline Inpatient ward & 3.832 & 0.326 & & \\
\hline Emergency & 3.921 & 0.353 & 8297 & 0,040 \\
\hline OR & 3.991 & 0.378 & 0.291 & 0.040 \\
\hline ICU & 4.040 & 0.312 & & \\
\hline
\end{tabular}

$\mathrm{OR}=$ operating room; $\mathrm{ICU}=$ intensive care unit. 
Most of the nurses thought that a person who makes a medical error is not the culprit (85.9\%), and the majority also agreed that when a medical error is reported, it should be tolerated (65.8\%). When we investigated the causes of medical errors, most of the nurses thought that the increased number of patients $(91.3 \%)$ and longer daily working hours (96\%) increase the number of medical errors, while reporting of medical errors decrease the number of medical errors (89.2\%). Additionally, the majority of the nurses surveyed believed that most medical errors were preventable ( $85.2 \%)$. Nurses also believed that medical errors were caused by a lack of communication $(58.4 \%)$ or knowledge $(68.5 \%)$ on the part of the person who made the error or by system failures $(61.1 \%)$.

Table 3. Responses of staff to items on the scale of attitudes toward medical errors $(N=149)$

\begin{tabular}{|c|c|c|}
\hline Items of a scale of attitudes towards medical errors & $\begin{array}{c}\text { Agree } \\
\%\end{array}$ & $\begin{array}{c}\text { Neutral, } \\
\text { disagree } \\
\%\end{array}$ \\
\hline \multicolumn{3}{|l|}{ Perception of medical errors } \\
\hline A person who makes a medical error is not guilty & 85.9 & 14.2 \\
\hline When a medical error is reported, it should be tolerated & 65.8 & 34.2 \\
\hline \multicolumn{3}{|l|}{ Causes of medical errors } \\
\hline Medical errors are caused by the lack of communication of the person making the error. & 58.4 & 41.7 \\
\hline Medical errors are caused by system failures. & 61.1 & 38.9 \\
\hline Medical errors are caused by lack of knowledge of the person who made the error & 68.5 & 31.5 \\
\hline Increased number of patients increases the number of medical errors & 91.3 & 8.7 \\
\hline Longer daily working hours increase medical errors & 96.0 & 4.0 \\
\hline Most of the medical errors are preventable & 85.2 & 14.8 \\
\hline Reporting medical errors increases patient safety & 89.2 & 10.7 \\
\hline \multicolumn{3}{|l|}{ Approach to medical errors } \\
\hline Medical errors and their causes must be openly discussed with staff & 96.0 & 10.4 \\
\hline All medical errors must be reported & 89.6 & 11.4 \\
\hline I refrain from reporting medical errors I did & 79.8 & 20.1 \\
\hline Institutional managers must show an approach that supports learning from mistakes. & 91.3 & 8.7 \\
\hline Medical errors and their causes should be discussed between the managers & 96.0 & 4.0 \\
\hline There is no need to report the medical error if it has been prevented before it has occurred & 19.5 & 80.6 \\
\hline Medical errors must be told to the patient and their relatives & 45.0 & 55.1 \\
\hline
\end{tabular}

When we examined nurses' approaches to medical errors, we learned that the majority of nurses believed that medical errors and their causes should be openly discussed with staff (96\%) and between managers (96\%). Additionally, 91.3\% of nurses thought that institutional managers should use an approach that supports learning from mistakes. While most nurses (89.6\%) believed that all medical errors must be reported, $79.8 \%$ of them said that they refrained from reporting medical errors for which they were responsible. Moreover, $19.5 \%$ of nurses believed that there was no need to report the medical error if it was prevented before it occurred. Finally, $45 \%$ of nurses thought that the patient and their relatives must be informed of medical errors (Table 3).

\section{Discussion}

Increased longevity of job experience among healthcare professionals has been found to be a contributing factor for error reporting (Nevalainen, Kuikka and Pitkälä, 2014; Samsuri, Pei Lin and Fahrni, 2015). In contrast, in this study, there was no correlation between attitudes toward medical errors and the years of job experience of specific staff members. However, our finding that the age of health staff had no impact on the reporting of medical errors is in line with Archer et al.'s (2017) review of the literature.

ICU nurses had a lower tendency to make medical errors, as well as higher ratings of patient safety culture, than inpatient ward nurses' (Karadağ, Ovayolu, Parlar Kılıç, Ovayolu and Göllüce, 2015; Yoo and Kim, 2017). Similarly, in this study, ICU nurses' attitudes toward medical errors were more positive than inpatient ward nurses' attitudes. Given that intensive care units provide lifesaving care for critically ill patients and perform work that is associated with significant risks, this finding was considered a favourable approach.

The nurses who responded to the questionnaire suggested that errors were primarily the result of increasing numbers of patients during each shift, workforce shortages and intensifying workloads, as well as individual factors, such as lack of knowledge and experience. Similarly, in a study by Roth, Brewer and Wieck (2017), which used the Delphi technique and 
obtained feedback from a panel of nursing experts, heavy workload and fatigue from working for many hours were in the list of the top ten human factors that contribute to medical errors. Furthermore, in another study by Al Malki, Endacott and Innes (2018) from Saudi Arabia, two domains of PSC - working condition and perception of management (which consists of hospital environment and management issues such as staffing levels) and training and education - were rated extremely low by health professionals.

While the majority of nurses believed that reporting medical errors decreased the number of medical errors and that all medical errors must be reported and conveyed to the patient and their relatives. Most of them also indicated that they refrained from reporting medical errors for which they were responsible. Indeed, the tendency to under-report is a problem in healthcare systems worldwide (Archer et al., 2017; Chiang et al., 2019; Matin et al., 2018). Similarly, previous literature has found that nurses and physicians usually do not report medical errors or inform patients about errors for which they are responsible, even though they agree that incident reporting is beneficial and that patients should be informed about medical errors (Bagenal, Sahnan and Shantikumar, 2016; McLennan, Diebold, Rich and Elger, 2016; Soydemir, Seren-İntepeler and Mert, 2017). However, nurses do tend to report more errors than physicians, because they are more aware of the reporting process, and they feel more comfortable reporting errors (Pimentel, Choi, Fiumara, Kachalia and Urman, 2017; Shu et al., 2014; Yung, Yu, Chu, Hou and Tang, 2016).

Most of the nurses participated in the study indicated that staff members are not the culprit when they make medical errors, and they believed that when a medical error is reported, it should be tolerated. According to Martinez and Lehmann's research (2013), punitive responses to error reporting might impede the transparent disclosure of errors. In Archer et al.'s (2017) theoretical review of the literature, fear of adverse consequences after reporting errors was found to be one of the top two factors for not reporting. Moreover, Howell et al.'s study (2017), which produced recommendations based on consensus between international experts, indicated that reporting systems regarding patient safety incidents must be designed to be "blame-free" and should be used for learning.

Working environments with a blame culture, complex reporting systems, lack of information about completing reports, feedback and communication following incident reporting and bad team working relationships, as well as senior staff influencing others not to report the medical errors, can affect the incident reporting rates negatively. Moreover, the level of harm, the cause of the incident and the frequency of the incident can affect reporting of medical errors. Findings suggest that health staff members are more likely to report incidents that occur infrequently and cause severe harm (Archer et al., 2017; Howell et al., 2017; Hung, Lee, Liang and Chu, 2016; Yoo and Kim, 2017).

Limitations of the study: This study contributes to the literature by determining nurses' attitudes toward medical errors. Nevertheless, this study is not without limitations. The study participants were selected only from those working in one university hospital, so the interpretation and generalization of the study results are limited. Another limitation of this study is that the survey did not ask about barriers to reporting, nor did it inquire about cultural elements that would facilitate reporting.

\section{Conclusion and Recommendations}

Nurses' attitudes toward medical errors were generally positive, meaning that they displayed a positive awareness of medical errors considering them as important issues. Moreover, ICU nurses were found to have more positive attitudes toward medical errors than nurses working in the inpatient ward. Nurses reported that the factors that caused medical errors to occur include an increasing number of patients during each shift, a workforce shortage, an intensifying workload, and individual factors, such as lack of knowledge and experience among some staff members. The majority of nurses believed that reporting medical errors decreased the number of medical errors and that all medical errors must be reported and conveyed to the patient and their relatives, but most nurses also refrained from reporting medical errors for which they were responsible. Further research is necessary to understand why nurses do not report medical errors.

The results of this study may be useful for nurse managers and leaders to reach a more comprehensive understanding of nurses' attitudes toward medical errors in Turkey, a developing country with emerging healthcare systems. The results may provide guidance to the administrative staff in supporting their personnel and improving their working environment, as they are the secondary victims of errors.

Ethics Committee Approval: Ethics Committee approval was obtained from Namik Kemal University Non-Invasive Clinical Research Ethics Committee date 04.03.2017 and numbered 43.

Conflict of Interest: Not reported.

Funding: None.

Informed consent: Informed consent was obtained from the participants. 


\section{References}

Al Malki, A., Endacott, R. \& Innes, K. (2018). Health professional perspectives of patient safety issues in intensive care units in Saudi Arabia. Journal of Nursing Management, 26(2), 209-218. doi: 10.1111/jonm.12536

Archer, S., Hull, L., Soukup, T., Mayer, E., Athanasiou, T., Sevdalis, N. \& Darzi, A. (2017). Development of a theoretical framework of factors affecting patient safety incident reporting: a theoretical review of the literature. British Medical Journal Open, 7(12), e017155. doi: 10.1136/bmjopen-2017-017155.

Bagenal, J., Sahnan, K. \& Shantikumar, S. (2016). Comparing the attitudes and knowledge toward incident reporting in junior physicians and nurses in a district general hospital. Journal of Patient Safety, 12(1), 51-53. doi: 10.1097/PTS.0000000000000103.

Chiang, H. Y., Lee, H. F., Lin, S.Y. \& Ma, S. C. (2019). Factors contributing to voluntariness of incident reporting among hospital nurses. Journal of Nursing Management, 27(4), 806-814. doi:10.1111/jonm.12744

Dykes, P. C., Rothschild, J. M. \& Hurley, A. C. (2010). Medical errors recovered by critical care nurses. The Journal of Nursing Administration, 40(5), 241-246. doi: 10.1097/NNA.0b013e3181da408e.

Güleç, D. \& Seren İntepeler, Ş. (2013). Tıbbi hatalarda tutum ölçeğinin geliştirilmesi. Hemşirelikte Araştırma Geliştirme Dergisi, 15(3), 26-41.

Harrison, R., Lawton, R., Perlo, J., Gardner, P., Armitage, G. \& Shapiro, J. (2015). Emotion and coping in the aftermath of medical error: A cross-country exploration. Journal of Patient Safety, 11(1), 28-35. doi: 10.1097/PTS.0b013e3182979b6f

Heyland, D. K., Ilan, R., Jiang, X., You, J. J. \& Dodek, P. (2016). The prevalence of medical error related to end-of-life communication in Canadian hospitals: results of a multicentre observational study. British Medical Journal Quality \& Safety, 25(9), 671-679. doi:10.1136/bmjqs-2015-004567

Howell, A. M., Burns, E. M., Hull, L., Mayer, E., Sevdalis, N. \& Darzi, A. (2017). International recommendations for national patient safety incident reporting systems: An expert Delphi consensus building process. British Medical Journal Quality \& Safety, 26(2), 150-163. doi:10.1136/bmjqs-2015-004456

Hung, C. C., Lee, B. O., Liang, H. F. \& Chu, T. P. (2016). Factors influencing nurses' attitudes and intentions toward medication administration error reporting. Japan Journal of Nursing Science, 13(3), 345-354. doi: 10.1111/jjns.12113.

James, J. T. (2013). A new, evidence-based estimate of patient harms associated with hospital care. Journal of Patient Safety, 9(3), $122-128$. doi: 10.1097/PTS.0b013e3182948a69

Karadağ, G., Ovayolu, Ö., Parlar Kiliç, S., Ovayolu, N. \& Göllüce, A. (2015). Malpractic in nursing: The experience in Turkey. International Journal of Nursing Practice, 21(6), 889-895. doi: 10.1111/ijn.12263.

Koehn, A. R., Ebright, P. R. \& Draucker, C. B. (2016). Nurses' experiences with errors in nursing. Nursing Outlook, 64(6), 566-574. doi: 10.1016/j.outlook.2016.05.012.

Makary, M. A. \& Daniel, M. (2016). Medical error-the third leading cause of death in the US. BMJ Quality and Safety, 353 : i2139.

Martinez, W. \& Lehmann, L. S. (2013). The "hidden curriculum" and residents' attitudes about medical error disclosure: Comparison of surgical and nonsurgical residents. Journal of the American College of Surgeons, 217(6), 1145-50. doi: 10.1016/j.jamcollsurg.2013.07.391.

Matin, B.K., Hajizadeh, M., Nouri, B., Rezaeian, S., Mohammadi, M. \& Rezaei, S. (2018). Period prevalence and reporting rate of medication errors among nurses in Iran: A systematic review and meta-analysis. Journal of Nursing Management, 26(5), 498-508. doi:10.1111/jonm. 12579

McLennan, S. R., Diebold, M., Rich, L. E. \& Elger, B. S. (2016). Nurses' perspectives regarding the disclosure of errors to patients: A qualitative study. International Journal of Nursing Studies, 54, 16-22. doi: 10.1016/j.ijnurstu.2014.10.001.

Nevalainen, M., Kuikka, L. \& Pitkälä, K. (2014). Medical errors and uncertainty in primary healthcare:A comparative study of coping strategies among young and experienced GPs. Scandinavian Journal of Primary Health Care, 32(2), 84-9. doi: 10.3109/02813432.2014.929820.

Pimentel, M. P. T., Choi, S., Fiumara, K., Kachalia, A. \& Urman, R. D. (2017). Safety culture in the operating room: Variability among perioperative healthcare workers. Journal of Patient Safety, Jun. doi: 10.1097/PTS.0000000000000385.

Roth, C., Brewer, M. \& Wieck, K. L. (2017). Using a Delphi method to identify human factors contributing to nursing errors. Nursing Forum, 52(3), 173-179. doi: 10.1111/nuf.12178. 


\section{Nurses' attitudes towards medical error}

Hemşirelerin tıbbi hatalara ilişkin tutumları

Sammer, C. E., Lykens, K., Singh, K. P., Mains, D. A. \& Lackan, N. A. (2010). What is patient safety culture? A review of the literature. Journal of Nursing Scholarship, 42(2), 156-165. doi:10.1111/j.1547-5069.2009.01330.x

Samsuri, S. E., Pei Lin, L. \& Fahrni, M. L. (2015). Safety culture perceptions of pharmacists in Malaysian hospitals and health clinics: A multicentre assessment using the safety attitudes questionnaire. British Medical Journal Open, 5(11):e008889. doi: 10.1136/bmjopen-2015-008889.

Shu, Q., Tao, H. B., Fu, J., Zhang, R. N., Zhou, J. \& Cheng, Z. H. (2014). The differences between doctors' and nurses' attitudes toward adverse event reporting and assessments of factors that inhibit reporting. American Journal of Medical Quality, 29(3): $262-263$. doi: $10.1177 / 1062860613505197$.

Soydemir, D., Seren Intepeler, S. \& Mert, H. (2017). Barriers to medical error reporting for physicians and nurses. Western Journal of Nursing Research, 39(10), 1348-1363. doi: 10.1177/0193945916671934.

Tawfik, D. S., Profit, J., Morgenthaler, T. I., Satele, D. V., Sinsky, C. A., Dyrbye, L. N., \& Shanefelt, T. D. (2018). Physician burnout, well-being, and work unit safety grades in relationship to reported medical errors. Mayo Clinic Proceedings, 93(11), 1571-1580. doi:10.1016/j.mayocp.2018.05.014

Tunçer Ünver, G. \& Harmanci Seren, A. K. (2018). Defining the patient safety attitudes and influencing factors of health professionals working at maternity hospitals. Journal of Nursing Management, 26(5), 579-586. doi:10.1111/jonm.12585

Winning, A. M., Merandi, J.M., Lewe, D., Stepney, L. M., Liao, N. N., Fortney, C. A. \& Gerhardt, C. A. (2018). The emotional impact of errors or adverse events on healthcare providers in the NICU: The protective role of co-worker support. Journal of Advanced Nursing. 74(1), 172180. doi: 10.1111/jan.13403.

Yoo, M. S. \& Kim, K. J. (2017). Exploring the influence of nurse work environment and patient safety culture on attitudes toward incident reporting. The Journal of Nursing Administration, 47(9), 434-440. doi: 10.1097/NNA.0000000000000510.

Yung, H. P., Yu, S., Chu, C., Hou, I. C. \& Tang, F. I. (2016). Nurses' attitudes and perceived barriers to the reporting of medication administration errors. Journal of Nursing Management, 24(5), 580-588. doi: 10.1111/jonm.12360.

Zhang, X., Li, Q., Guo, Y. \& Lee, S.Y. (2019). From organizational support to second victim-related distress: role of patient safety culture. Journal of Nursing Management, 27(8), 1818-1825. doi:10.1111/jonm.12881 